\title{
Technology Acceptance of a Novel Mobile Learning Application among University Undergraduates
}

\author{
Hafizul Fahri Hanafi ${ }^{\mathrm{a}}$, Nur Azlan Zainuddin ${ }^{\mathrm{b}}$, Mohd Helmy Abd Wahab ${ }^{\mathrm{c}}$, \\ Asma Hanee Ariffin ${ }^{\mathrm{d}}$ \\ ${ }^{a}$ Faculty of Art, Computing and Creative Industry, Universiti Pendidikan Sultan Idris, Malaysia, \\ hafizul@fskik.upsi.edu.my \\ ${ }^{b}$ Faculty of Art, Computing and Creative Industry, Universiti Pendidikan Sultan Idris, Malaysia, \\ nurazlan@fskik.upsi.edu.my
}

${ }^{c}$ Faculty of Electrical and Electronic Engineering,Universiti Tun Hussein Onn Malaysia, helmy@uthm.edu.my

${ }^{d}$ Faculty of Art, Computing and Creative Industry, Universiti Pendidikan Sultan Idris, Malaysia, asma@fskik.upsi.edu.my

\begin{abstract}
This paper identifies factors affecting the adoption of mobile learning application in the classroom. The principles of the Innovation Diffusion Theory (IDT) and Technology Acceptance Model (TAM) were adopted as the main elements that were investigated in this study, namely relative advantage, complexity, mobile learning acceptance, and intention to use mobile learning. The research design was based on a quantitative approach using an online survey involving a group of 200 undergraduates. Data collected were analyzed using the Comparative Fit Index (CFI) and Tucker-Lewis Index (TLI) on AMOS 20.0. Interestingly, the main research findings showed that all the indices fit the hypothesized model perfectly and all the technology acceptance constructs were significantly correlated. The finding encourage that UPSI's undergraduates are perceptive to utilizing mobile learning approach with the utilize of novel mobile applications, which surely would have an enormous impact on the current teaching and learning practice in the campus. From the practical standpoint, such a learning paradigm would become more prevalent in many institutions of higher learning as mobile technology keeps on improving and becoming more affordable, hence enabling more students to gain unrivaled access to mobile online learning content.
\end{abstract}

\section{Keywords:}

Innovation Diffusion Theory (IDT), Technology Acceptance Model (TAM), mobile learning

\section{INTRODUCTION}

Mobile learning is a novel learning paradigm that has thoroughly varied the landscape of teaching and learning, appealing in a host of benefits to students of various levels, especially for university students (Al-Emran et al., 2016). As a consequence, students have greater access to learning opportunities on a scale that was never imagined before. (Yildirim et al., 2004; Chang et al., 2018). Such access is hardly remarkable given that mobile learning or m-learning can take place virtually anytime, anywhere, thus transcending temporal and geographical barriers (Kukulska-Hulme \& Traxler, 2005). In light of the rapidly changing advancement in computer technology, notably in mobile technology, students are able to partake in learning activities in which two-way communication has become a norm. For instance, students can now converse with their peers readily using mobile devices (e.g., smart phones), with instructors impersonating the role of a mediator, thus making learning collaboratively and engaging (Vavoula \& Sharples, 2009). 
Recent studies of m-learning have conferred that a majority of students have a proclivity to engage in mobile learning. As such, learning strategies have to be delicately planned such as to create an environment that supports such a learning paradigm (Furió et al., 2015; Mouza \& Barrett-Greenly, 2015). For example, lecturers or teachers have to extemporize their teaching approaches such as to support m-learning with which they can harmonize important elements of teaching using technology more efficiently and effectively (Luo, 2017; Liu, 2011).

Premised on this learning context, this study was carried out to examine factors that might affect user acceptance of undergraduates in utilizing mobile learning. Particularly, the focus of the research was on examining user acceptance from the viewpoints of innovation diffusion theory (IDT) and the technology acceptance model (TAM) (Davis, 1989; Rogers et al., 2005; Cheon et al., 2012). Such a focus was asserted given both theory and model have been broadly practiced in many studies sharpening on technology acceptance and use of new technologies in various academic disciplines, in particular in learning and training. Grounded in such theory, the research findings could be interpreted more accurately that would surely have an enormous impact on understanding the role impersonated by mobile learning.

\section{LITERATURE REVIEW}

\section{Innovation diffusion theory (IDT)}

IDT was developed by Rogers (2003, 2005) who scrutinized the correlations of multiple varieties of innovation adoption using several aspects of users as a function of their preferences and attitudes. In fact, this theory has been favorably implemented in many studies that emphasized on identifying factors related to innovation and diffusion of technology (Lee \& Rha, 2016). In particular, this theory accommodates researchers to examine overriding factors that make users (e.g., students) to accept or to reject an innovative application or approach or method, such as m-learning approach (Agarwal \& Karahanna, 2000). In principle, the IDT theory is based on a set of factors comprising five main elements that characterize the adoption of a new technology. The five elements are advantages, compatibility, complexity, trialability, and visibility. In addition, other important components that shape consumer intention is the relative advantage and compatibility in adopting new technologies, such as m-learning approach (Lu et al., 2011). For this study, the focus was on measuring the influences of perceived relative advantages and compatibility of learners to mlearning that could help improve students' learning performance by making them more engaged and diligent in the learning process (Anderson et al., 1998; Liu et al., 2010). Figure 1 explicates the five stages of the innovation-decision process. 


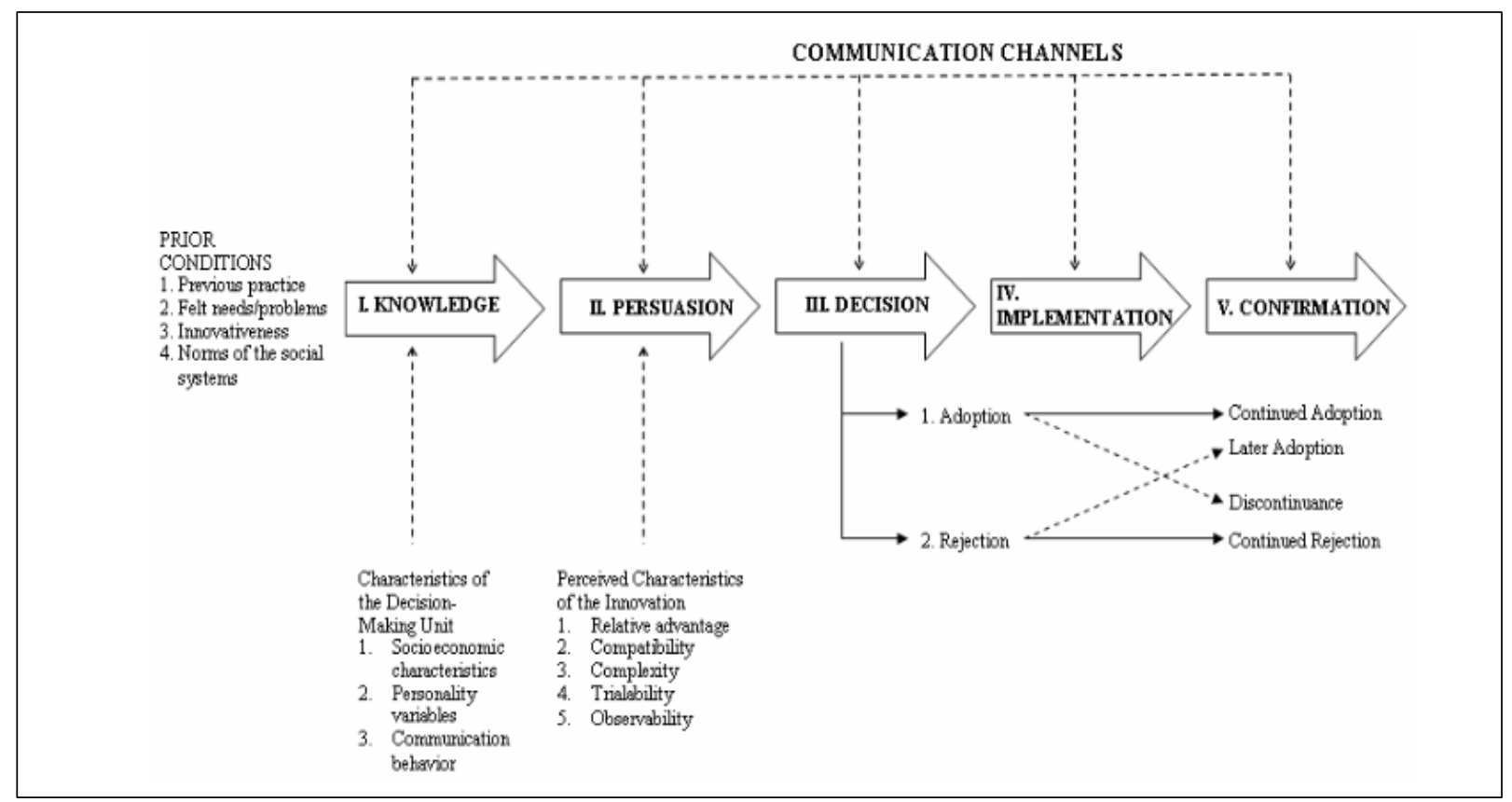

Figure 1: A Model of Five Stages in the Innovation-Decision Process (Rogers, 2003)

\section{Technology Acceptance Model (TAM)}

Technology acceptance model is a well-established model that has been applied to inscribe the issues on how the user or learner can adapt to a new technology and be able to utilize it successfully in the learning (Davis, 1989; Schierz et al., 2010). Typically, the TAM model comprises three main elements or constructs, namely Perceived Usefulness (PU), Perceived Ease of Use (PEOU), and Attitudes Towards Usage (ATU) to explain the adoption of technology (Davis, 1989) as manifested in Figure 2.

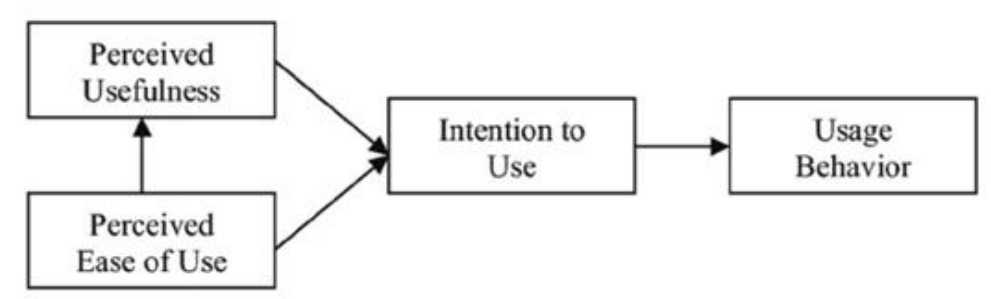

Figure 2: The technology acceptance model (TAM) by Davis (1989) 


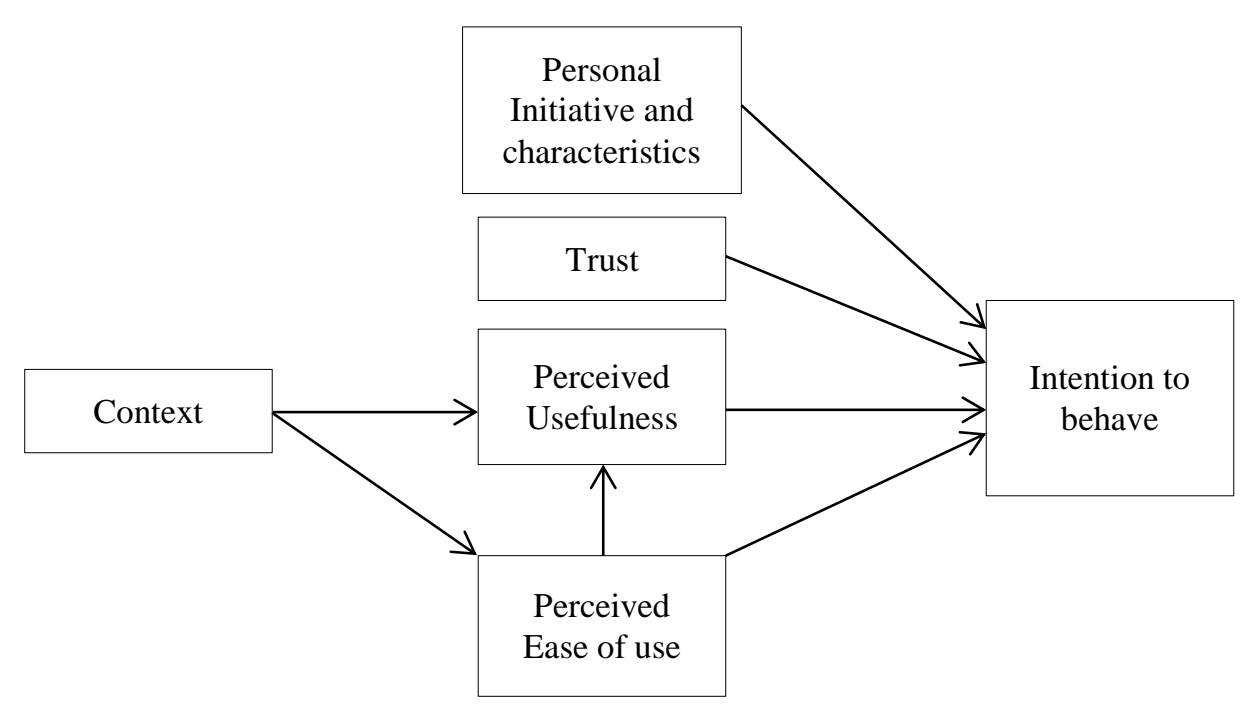

Figure 3: Mobile services Acceptance model (Gao et al., 2008)

Succeeding, the TAM model (Davis, 1989) was refined by Gao et al. (2008) to include new constructs, namely as trust and personal initiative. Furthermore, the characteristic of the mobile services acceptance model as depicted in Figure 3. Subsequently, this study sharpened on such a novel technology that is extensively utilized among young learners who naturally preferred to engage in technology-assisted learning, such as mobile learning, through which they could become more motivated and engaged (Irby \& Strong, 2015). Nevertheless, some researchers have forewarned the challenges in using m-learning, which could be counterproductive if they are not properly addressed (Trebbi, 2011; Park, 2011). As such, lecturers or instructors demand to implement some initiatives, such as learning portfolios, to their students such that the latter would be amenable and receptive to using such a novel learning approach (Demirbilek, 2010). Of late, the number of learning institutions of elementary, secondary, and tertiary levels, adopting m-learning has progressed, given the strong emphasis on the use of digital information and portfolios (Cheon et al., 2012). In recognition of its advantages (such as its ability to provide rich, multimedia contents and to support multi-channel data transmission), it is anticipated that the number of universities and schools adopting m-learning will continue to grow (Thornton \& Houser, 2005). In this regard, the policy maker of such learning institutions ought to necessitate the initiative to encourage the adoption of m-learning by focusing on the important factors deemed significantly to the successful implementation of such a learning approach (Carlsson et al., 2006).

\section{METHODOLOGY}

The methodology utilized in this investigation was based on a quantitative approach utilizing a survey. The sample of the study consisted of 200 undergraduates of Universiti Pendidikan Sultan Idris (UPSI). They were given a simple survey questionnaire necessitating them to answer a set of survey items pertaining to three constructs, namely as relative advantage, complexity, and intention to use mobile learning. Next, the responses were evaluated along a 5-point Likert scale, ranging from "1" (strongly disagree) to "5" (strongly agree), as counsel by Norman (2010). The measure of technology readiness was adopted from the work of Parasuraman (2000) with the deliberation of the learning construct of student learning in mobile environments. Furthermore, the dependent variable of this study was students' intention to utilize mobile learning in the classroom, which was marked by two items relating to their intention to exercise such a learning procedure. In addition, appropriate demographics of all the participants were accumulated, notably gender (Joo et al., 2016). 


\section{Data collection and pilot test}

The survey data were congregated from an online survey in which a questionnaire was administered using google document to elicit important information of such technology acceptance constructs, which have been tested and validated in previous studies, manifesting high reliability and validity. Table 1 compiles the descriptive statistics of the surveyed respondents.

Table 1: The descriptive statistics of the surveyed respondents

\begin{tabular}{llll}
\hline Variable & Category & Frequency & Percentage \\
\hline \multirow{2}{*}{ Gender } & Male & 40 & $20 \%$ \\
& Female & 160 & $80 \%$ \\
Mean Age & First Semester & 33 & 39.5 \\
$(\mathbf{1 9 . 5 )}$ & & & \\
& Second Semester & 167 & $60.5 \%$ \\
Courses & Software & 40 & $25 \%$ \\
& Engineering & & \\
& Arts & 60 & $35 \%$ \\
& Creative Multimedia & 100 & $50 \%$ \\
\hline
\end{tabular}

\section{Data analysis}

The survey data collected were analyzed using the Comparative Fit Index (CFI) and Tucker Lewis Index (TLI) on AMOS 20.0. More importantly, the main research findings showed that all the indices fit the hypothesized model perfectly (CFI $>=0.90$ and TLI $>=$ 0.90) (Hair et al., 2006).

\section{RESULTS}

\section{The measurements of testing constructs}

Cronbach's Alpha values were computed to examine the three main technology acceptance constructs. The computation announced that all the reliability coefficients were quite high, far exceeding the recommended threshold of 0.7 (Nunnally, 1978). In addition, the values of the CFA were observed to be significant, as attested by significance values of less than 0.001 $(\mathrm{p}<0.001)$. Besides, the average variance extracted (AVE) and Composite Reliability $(\mathrm{CR})$ of all the constructs was greater than 0.50 , which is an acceptable value for the required threshold (Cunningham, 2006). Table 2 compiles the measurements of all constructs of the statistical model, in particular, the appropriate convergent validity of such constructs. 
Table 2: The measurements of technology acceptance constructs of the mobile learning model

\begin{tabular}{|c|c|c|c|c|c|}
\hline Construct & $\begin{array}{c}\text { Standardize Factor } \\
\text { Loading }\end{array}$ & $\begin{array}{c}\text { t- } \\
\text { values }\end{array}$ & $\mathbf{C R}$ & AVE & $\begin{array}{c}\text { Cronbach's } \\
\text { Alpha } \\
\text { Values }\end{array}$ \\
\hline Relative advantage & 0.7564 & 13.4525 & 0.912 & 0.921 & 0.81 \\
\hline Complexity & 0.8657 & 19.5242 & 0.925 & 0.941 & 0.76 \\
\hline Mobile learning & 0.7852 & 13.5245 & 0.956 & 0.951 & 0.78 \\
\hline Acceptance & & & & & \\
\hline $\begin{array}{l}\text { Intention to use } \\
\text { mobile learning }\end{array}$ & 0.835 & 19.5245 & 0.947 & 0.952 & 0.87 \\
\hline
\end{tabular}

As highlighted in Table 3, the structural path of the model explicates a significant effect on the student acceptance of mobile learning environment. Concretely, the standardized structure path of the model indicates that relative advantage $(\beta=-0.275, \mathrm{p}<$ $0.001)$ and complexity $(\beta=0.440, \mathrm{p}<0.001)$ had a significant effect on students' learning adoption, demonstrating about $49 \%$ of the variance in such a construct.

Table 3: Means and correlation and discriminant validity of mobile learning acceptance

\begin{tabular}{lccccc}
\hline \multicolumn{1}{c}{ Construct } & Mean & SD & (1) & (2) & (3) \\
\hline $\begin{array}{l}\text { (1) Relative advantage } \\
\text { (2) Mobile Learning }\end{array}$ & 2.8454 & 00745 & 0.899 & & \\
$\begin{array}{l}\text { Acceptance } \\
\text { (3) Intention to use mobile }\end{array}$ & 2.8457 & 0.7458 & 00785 & $0.175^{* *}$ & \\
learning & 3.2542 & $0 . .9454$ & $0.4524^{* *}$ & - & -0.2155 \\
\hline${ }^{* p}<0.05, * * \mathrm{p}<0.01$. & & & & $0.2454^{* *}$ & \\
\hline
\end{tabular}

As depicted in Table 3, all the values of AVE had been well envisioned in relations to the item, which were more prominent than the correlations between any two constructs based on the discriminant validity model (Fornell \& Larcker, 1981).

Table 4: Result of structural model for Mobile learning acceptance

\begin{tabular}{|c|c|c|c|c|}
\hline Paths & Estimates & $\begin{array}{c}\text { t- } \\
\text { Values }\end{array}$ & $\begin{array}{c}\text { p- } \\
\text { Values }\end{array}$ & Results \\
\hline $\begin{array}{l}\text { H1a: Relative advantages (Intention to } \\
\text { use mobile learning) }\end{array}$ & $-0.275 * * *$ & 10.6777 & $<0.001$ & Supported \\
\hline $\begin{array}{l}\text { H1b: Relative advantages (Mobile } \\
\text { learning adoption) }\end{array}$ & $0.440 * * *$ & 6.2454 & $<0.001$ & Supported \\
\hline $\begin{array}{l}\text { H2a: Complexity advantages (Intention } \\
\text { to use mobile learning) }\end{array}$ & $0.414 * * *$ & 0.745 & $<0.001$ & Supported \\
\hline $\begin{array}{l}\text { H2b: Complexity advantages (Mobile } \\
\text { learning adoption) }\end{array}$ & $0.3721 * * *$ & 6.9545 & $<0.001$ & Supported \\
\hline $\begin{array}{l}\text { H3: Mobile learning intention (Intention } \\
\text { to use mobile learning) }\end{array}$ & $\begin{array}{c}- \\
0.3545 * * * \\
\end{array}$ & -6.345 & $<0.001$ & Supported \\
\hline
\end{tabular}




\section{DISCUSSION}

Overall, all of the results of this investigation explicate that all the investigated technology acceptance constructs (namely relative advantage, complexity, mobile learning acceptance, and intention to use mobile learning) based on the Mobile Services Acceptance model were significantly associated with one another. Such a promising finding conjecture that UPSI's undergraduates are receptive to appropriating mobile learning approach with the use of novel mobile applications, which surely would have a tremendous impact on the current teaching and learning practice in the campus environment. From the pragmatic standpoint, such a learning paradigm would metamorphose more prevalent in many institutions of higher learning as mobile technology persevere bettering and shifting more affordable, thus permitting more students to attain greater access to mobile online learning content. Admittedly, more studies are entailed to investigate if such adoption of mobile learning could be befriended over the long term, the impact of which student learning would be heightened to ease them learn more efficiently and effectively. In addition, future studies should be carried out under the framework of recently competing for theories or models, such as the self-determination theory, to further expose elements that could forgather and motivate students in practicing novel learning tools or applications in mobile learning.

\section{References}

Agarwal, R., \& Karahanna, E. (2000). Time flies when you're having fun: Cognitive absorption and beliefs about information technology usage. MIS quarterly, 665-694.

Al-Emran, M., Elsherif, H. M., \& Shaalan, K. (2016). Investigating attitudes towards the use of mobile learning in higher education. Computers in Human Behavior, 56, 93-102.

Anderson, T., Varnhagen, S., \& Campbell, K. (1998). Faculty adoption of teaching and learning technologies: Contrasting earlier adopters and mainstream faculty.

Carlsson, C., Carlsson, J., Hyvonen, K., Puhakainen, J., \& Walden, P. (2006, January). Adoption of mobile devices/services - searching for answers with the UTAUT. In System Sciences, 2006. HICSS'06. Proceedings of the 39th Annual Hawaii International Conference on (Vol. 6, pp. 132a-132a). IEEE.

Chang, C. Y., Lai, C. L., \& Hwang, G. J. (2018). Trends and research issues of mobile learning studies in nursing education: A review of academic publications from 1971 to 2016. Computers \& Education, 116, 28-48.

Cheon, J., Lee, S., Crooks, S. M., \& Song, J. (2012). An investigation of mobile learning readiness in higher education based on the theory of planned behavior. Computers \& Education, 59(3), 1054-1064.

Cheon, J., Lee, S., Crooks, S. M., \& Song, J. (2012). An investigation of mobile learning readiness in higher education based on the theory of planned behavior. Computers \& Education, 59(3), 1054-1064.

Cunningham, E., Holmes-Smith, P., \& Coote, L. (2006). Structural equation modeling: From the fundamentals to advanced topics. Streams Statsline, Melbourne. 
Davis, F. D. (1989). Perceived usefulness, perceived ease of use, and user acceptance of information technology. MIS quarterly, 319-340.

Davis, F. D. (1989). Perceived usefulness, perceived ease of use, and user acceptance of information technology. MIS quarterly, 319-340.

Demirbilek, M. (2010). Investigating attitudes of adult educators towards educational mobile media and games in eight European countries. Journal of Information Technology Education: Research, 9, 235-247.

Fornell, C., \& Larcker, D. F. (1981). Evaluating structural equation models with unobservable variables and measurement error. Journal of marketing research, 39-50.

Furió, D., Juan, M. C., Seguí, I., \& Vivó, R. (2015). Mobile learning vs. traditional classroom lessons: a comparative study. Journal of Computer Assisted Learning, 31(3), 189-201.

Gao, S. (2011). High level modeling and evaluation of multi-channel services. Norwegian University of Science and Technology.

Hair, J. F., Black, W. C., Babin, B. J., Anderson, R. E., \& Tatham, R. L. (2006). Multivariate data analysis 6th ed. Uppersaddle River: Pearson Prentice Hall.

Irby, T. L., \& Strong, R. (2015). A synthesis of mobile learning research implications: Agricultural faculty and student acceptance of mobile learning in academia. NACTA Journal, 59(1), 10.

Joo, Y. J., Kim, N., \& Kim, N. H. (2016). Factors predicting online university students' use of a mobile learning management system (m-LMS). Educational Technology Research and Development, 64(4), 611-630.

Kukulska-Hulme, A., \& Traxler, J. (Eds.). (2005). Mobile learning: A handbook for educators and trainers. Psychology Press.

Lee, J. M., \& Rha, J. Y. (2016). Personalization-privacy paradox and consumer conflict with the use of location-based mobile commerce. Computers in Human Behavior, 63, 453462.

Liu, S. H. (2011). Factors related to pedagogical beliefs of teachers and technology integration. Computers \& Education, 56(4), 1012-1022.

Liu, Y., Han, S., \& Li, H. (2010). Understanding the factors driving m-learning adoption: a literature review. Campus-Wide Information Systems, 27(4), 210-226.

Lu, Y., Yang, S., Chau, P. Y., \& Cao, Y. (2011). Dynamics between the trust transfer process and intention to use mobile payment services: A cross-environment perspective. Information \& Management, 48(8), 393-403.

Luo, N., Zhang, M., \& Qi, D. (2017). Effects of different interactions on students' sense of community in e-learning environment. Computers \& Education, 115, 153-160. 
Mouza, C., \& Barrett-Greenly, T. (2015). Bridging the app gap: An examination of a professional development initiative on mobile learning in urban schools. Computers \& Education, 88, 1-14.

Norman, G. (2010). Likert scales, levels of measurement and the "laws" of statistics. Advances in health sciences education, 15(5), 625-632.

Nunnally, J. C., \& Bernstein, I. H. (1978). Psychometric theory.

Parasuraman, A. (2000). Technology Readiness Index (TRI) a multiple-item scale to measure readiness to embrace new technologies. Journal of service research, 2(4), 307-320.

Park, Y. (2011). A pedagogical framework for mobile learning: Categorizing educational applications of mobile technologies into four types. The International Review of Research in Open and Distributed Learning, 12(2), 78-102.

Rogers, E. M., Medina, U. E., Rivera, M. A., \& Wiley, C. J. (2005). Complex adaptive systems and the diffusion of innovations. The Innovation Journal: The Public Sector Innovation Journal, 10(3), 1-26.

Rogers, E.M. (2003). Diffusion of innovations (5th Ed.). New York: Free Press.

Schierz, P. G., Schilke, O., \& Wirtz, B. W. (2010). Understanding consumer acceptance of mobile payment services: An empirical analysis. Electronic commerce research and applications, 9(3), 209-216.

Thornton, P., \& Houser, C. (2005). Using mobile phones in English education in Japan. Journal of computer assisted learning, 21(3), 217-228.

Trebbi, T. (2011). The potential of ICT for a new educational paradigm: Toward generalizing access to knowledge. American Journal of Distance Education, 25(3), 152-161.

Vavoula, G., \& Sharples, M. (2009). Meeting the challenges in evaluating mobile learning: a 3-level evaluation framework. International Journal of Mobile and Blended Learning, $1,54-75$.

Yildirim, S., Goktas, Y., Temur, N., \& Kocaman, A. (2004). A Checklist for a Good Learning Management System (LMS). Turk Egitim Bilimleri Dergisi, 4(2), 455-462. 